\title{
Unravelling the Photoprotection Capacity of Resveratrol on Histidine Oxidation
}

\author{
Jael R. Neyra Recky, M. Laura Dántola and Carolina Lorente *(D)
}

check for updates

Citation: Neyra Recky, J.R.; Dántola, M.L.; Lorente, C. Unravelling the Photoprotection Capacity of Resveratrol on Histidine Oxidation. Photochem 2021, 1, 209-219. https://doi.org/10.3390/ photochem 1020012

Academic Editor: Michael Moustakas

Received: 14 July 2021

Accepted: 13 August 2021

Published: 18 August 2021

Publisher's Note: MDPI stays neutral with regard to jurisdictional claims in published maps and institutional affiliations.

Copyright: (c) 2021 by the authors. Licensee MDPI, Basel, Switzerland. This article is an open access article distributed under the terms and conditions of the Creative Commons Attribution (CC BY) license (https:/ / creativecommons.org/licenses/by/ $4.0 /)$.
Departamento de Química, Facultad de Ciencias Exactas, Instituto de Investigaciones Fisicoquímicas Teóricas y Aplicadas (INIFTA), Universidad Nacional de La Plata, CCT La Plata-CONICET, Boulevard 113 y 64, La Plata 1900, Argentina; jneyrarecky@inifta.unlp.edu.ar (J.R.N.R.); ldantola@inifta.unlp.edu.ar (M.L.D.)

* Correspondence: clorente@inifta.unlp.edu.ar; Tel.: +54-221-425-7291

\begin{abstract}
Exposure to sun radiation causes great oxidative stress and activates a numerous of defense mechanisms in living systems, such as the synthesis of antioxidants. Resveratrol (RSV), a naturally occurring stilbene molecule, has antioxidant properties and is synthesized in large amounts when plants are under high oxidative stress. Likewise, under UV and visible radiation, biomolecules are oxidized, losing their physiological properties and, therefore, avoiding the harmful effects of solar radiation is crucial in order to preserve the functionality of cellular components. In proteins, one essential component that is often susceptible to degradation is the amino acid histidine (His), which can be modified via several oxidizing mechanisms. In this article, we evaluate the photoprotection capacity of RSV in photosensitized oxidation of His, which is initiated with a one-electron transfer reaction, yielding the His radical cation $\left(\mathrm{His}^{\bullet+}\right)$. The photoprotective properties of RSV are evaluated using kinetics analysis during steady-state irradiation and laser flash photolysis experiments. The experimental results reveal that the presence of RSV in the solution causes an evident decrease of the His consumption initial rates as a result of a reaction between His ${ }^{\bullet+}$ and RSV that recovers the amino acid. In addition, we conclude that during its antioxidant action, RSV is consumed being a sacrificial antioxidant.
\end{abstract}

Keywords: resveratrol; photoprotection; antioxidant; histidine; pterin; photosensitization

\section{Introduction}

Interest in resveratrol (RSV) has grown steadily for about five decades, since it was discovered that it is synthesized in some plants in response to oxidative stress. In 1976, it was found that RSV is accumulated in grapevines as a non-specific response to stress situations, such as an infection or UV radiation exposure [1]. At that time, RSV was classified as a phytoalexin, as it was evident that it is synthesized in response to stressful situations. Phytoalexins are a family of chemically unrelated molecules, which are found in plants and involved in their defense reactions during a variety of injuries [2]. When classifying this family of compounds according to their chemical structure, a subgroup of stilbenes was included, having a common structure of two aromatic rings joined by a methylene bridge. RSV belongs to the stilbene subgroup and is found in plants as trans3,5,4'-trihydroxy-stilbene (Figure 1). RSV has been found in more than 70 plant species, including edible fruits and vegetables (grapes, cranberries, peanuts, cocoa) [3].

Due to the high concentrations of RSV in wine, it plays a key role in the "French paradox", which relates an unhealthy diet including cheese and red wine with a low incidence of cardiovascular events [4]. Recently, it was demonstrated that RSV prevents guanine nucleotide ( $2^{\prime}$-deoxyguanosine $5^{\prime}$-monophosphate, dGMP) from one-electron oxidation by giving an electron to the formed guanine radical $\left(\mathrm{dGMP}(-\mathrm{H})^{\bullet}\right)$, recovering the nucleotide [5]. These results suggest that RSV may prevent oxidation of DNA molecules and the associated consequences, such as mutations and carcinogenic lesions. 
Under exposure to UV-A and visible radiation, biomolecules are degraded by photosensitized oxidations, by both type I and type II photosensitized mechanisms [6]. The type I mechanism involves the initial formation of radicals from a given biomolecule, such as amino acids, lipids, or nucleotides; however, in type II mechanism, singlet oxygen $\left({ }^{1} \mathrm{O}_{2}\right.$ $\left({ }^{1} \Delta_{\mathrm{g}}\right)$, denoted as $\left.{ }^{1} \mathrm{O}_{2}\right)$ is formed by energy transfer from the sensitizer to molecular oxygen, which readily oxidizes the biomolecules [6].<smiles>Oc1ccc(/C=C/c2cc(O)cc(O)c2)cc1</smiles>

trans-RSV<smiles>Nc1nc2nccnc2c(=O)[nH]1</smiles><smiles>[NH3+]C(Cc1c[nH]c[nH+]1)C(=O)[O-]</smiles>

Figure 1. Chemical structure of resveratrol (RSV), histidine $\left(\mathrm{HisH}^{+}\right)$, and pterin (Ptr) at $\mathrm{pH} 4.5$.

In biological systems, proteins constitute the majority component, and their exposure to an oxidizing environment damages these biomolecules, causing alterations in their structure and function. The oxidation of amino acids leads to modifications in proteins such as unfolding, aggregation, fragmentation, and/or inactivation of enzymes, affecting a wide range of cellular and biochemical physiological functions [7]. Preserving the integrity of amino acids is essential for maintaining the structure and functionality of proteins. Serious damage is caused by the cross-linking of proteins due to the formation of dimers between two tyrosines (Tyr) or the formation of disulfide bridges between cysteines [7]. Previously, it was observed that the presence of RSV prevents this oxidative modification of tyrosine by inhibiting the formation of tyrosine dimers [8]. According to this observation, RSV is likely to be able to protect proteins in other oxidative electron transfer processes. Histidine (His) is one of the basic amino acids found in proteins, which plays a critical role in plant growth and development [9]. His is extremely susceptible to oxidation and its degradation causes severe modifications in proteins, often leading to the loss of their functionality due to its presence in the catalytic sites of several enzymes, since it has been demonstrated that His oxidation is essential for the active enzymatic protein conformation [10]. Furthermore, at the reaction center of photosystem II, the enzyme that uses sunlight to oxidize water to molecular oxygen, His is a crucial amino acid that is involved in a proton-coupled electron transfer (PCET) with Tyr [11]. His is extremely sensitive to metal-catalyzed oxidation, electrophilic modifications, and UV-visible radiation [12]. His is not significantly affected directly by UV-A or visible radiation (sun exposure), although it is extremely reactive in the presence of a suitable sensitizer (Sens), such as phthalocyanines, flavins, pterins [13-15]. The photodegradation of His is clearly $\mathrm{pH}$-dependent, and the mechanisms involved in its oxidation could be type I and/or type II $[13,15,16]$. At neutral and basic $\mathrm{pH}$, the reaction between ${ }^{1} \mathrm{O}_{2}$ and His becomes relevant, since only the neutral and anionic forms of the amino acid are significantly reactive and both mechanisms compete [15]; however, at 
$\mathrm{pH}$ below 6, the imidazole group is protonated and a PCET was reported as the main mechanism (type I mechanism, reaction 1) [15].

$$
{ }^{3} \text { Sens }^{*}+\mathrm{HisH}^{+} \stackrel{\text { PCET }}{\longrightarrow} \mathrm{SensH}^{\bullet}+\mathrm{His}^{\bullet+}
$$

The photosensitizing properties of pterin (Ptr, Figure 1) have been extensively reported, namely the target biomolecules, nucleotides, and amino acids, [17] including His. Under UV-A radiation, Ptr acts through both type I [18] and type II [19] photosensitized oxidation mechanisms. Regarding His, it was previously demonstrated that Ptr-photosensitized oxidation at $\mathrm{pH}<6.0$ occurs through a type I mechanism, while ${ }^{1} \mathrm{O}_{2}$ does not contribute appreciably to its degradation [15].

In the study reported here, we investigated the photoprotective effects of RSV on the Ptr-photosensitized oxidation of His under UV-A irradiation $(365 \mathrm{~nm})$ in acidic aqueous solution. At that wavelength, Ptr is the major absorbing species, since His does not absorb and RSV poorly absorbs radiation (Figure 2). The experiments were performed at $\mathrm{pH} 4.5$, at which His is present mostly in its protonated form $\left(\mathrm{HisH}^{+}\right.$, Figure 1). The photochemical reactions were analyzed by laser flash photolysis (LFP), UV-visible spectrophotometry, and chromatography (HPLC-UV). The mechanistic aspects of the antioxidant action of RSV on His degradation are discussed.

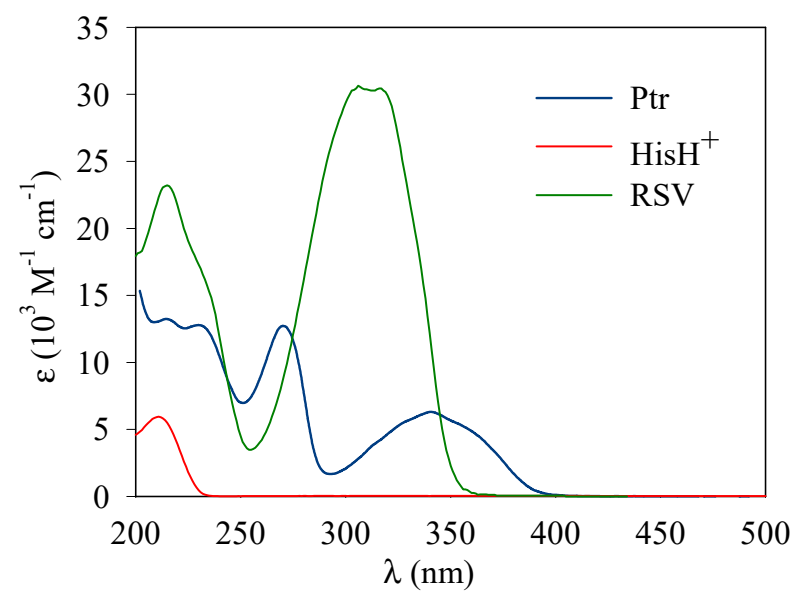

Figure 2. Absorption spectra of Ptr (blue line), His (red line), and RSV (green line) in air-equilibrated aqueous solutions at $\mathrm{pH} 4.5$.

The results are useful for clarifying the underlying action mechanism of the photoprotection effects of RSV and give evidence of the antioxidant mechanisms that involve this plant-derived stilbene.

\section{Materials and Methods}

General. Pterin (Ptr) (purity > 99\%, Schircks Laboratories, Bauma, Switzerland) and histidine (His, $>98 \%$, Sigma Chemical Co., St. Louis, MI, USA) were used without further purification after checking for impurities using HPLC. Formic acid ( $\mathrm{HCOOH})$ was purchased from Sigma Chemical Co.; trans-3,5, $4^{\prime}$-trihydroxy-stilbene (RSV, purity $>99 \%$, Shaanxi Berries Biochemical Co., Ltd., Beijing, China) was purchased from Elisium (Buenos Aires, Argentina). Experiments were carried out in aqueous solutions prepared using deionized water (specific electrical resistance of water was $\sim 10 \mathrm{M} \Omega \mathrm{cm}$ ) further purified in a Milli Q Reagent Water System apparatus. The $\mathrm{pH}$ measurements were performed with a sensION+ pH31 GLP pH meter combined with a 5010T pH electrode (Hach Latam, México, México). The final $\mathrm{pH}$ of the aqueous solutions ( $\mathrm{pH} 4.5$ ) was adjusted by adding very small aliquots (few $\mu \mathrm{L}$ ) of concentrated $(0.1-2 \mathrm{M}) \mathrm{HCl}$ or $\mathrm{NaOH}$ solutions using a micropipette. The ionic strength was ca. $10^{-3} \mathrm{M}$ in all experiments. 
Steady-state irradiation. Aqueous solutions containing $\operatorname{Ptr}(\sim 60 \mu \mathrm{M})$ and His $(\sim 100 \mu \mathrm{M}$ or $700 \mu \mathrm{M}$ ) were irradiated in $0.4 \mathrm{~cm}$ path length quartz cells at room temperature with Rayonet RPR3500 lamps with emission centered at $365 \mathrm{~nm}$ (Southern N.E. Ultraviolet Co., Branford, CT, USA) at variable distances between 0 and $3 \mathrm{~cm}$. The spectral discrimination was achieved using filters with bandwidths ( $\mathrm{fwhm}$ ) of $\sim 20 \mathrm{~nm}$. The incident photon flux density $\left(q_{n, p}^{0, V}\right)$ at the excitation wavelength $(365 \mathrm{~nm})$ was $2.5( \pm 0.2) \times 10^{-5}$ Einstein $\mathrm{L}^{-1} \mathrm{~s}^{-1}$, which was determined as previously described $[20,21]$. The experiments were performed in aerated aqueous solutions at $\mathrm{pH} 4.5$ and under conditions of reduced environmental light.

UV-Visible spectrophotometric analysis. UV-visible absorption spectra were registered on a Shimadzu UV-1800 spectrophotometer. Measurements were made in quartz cells with 0.4 and $1 \mathrm{~cm}$ optical path lengths.

High-Performance Liquid Chromatography (HPLC). A Prominence equipment from Shimadzu (Kyoto, Japan) containing a LC-20AT solvent delivery module, DGU-20A5 online degasser, CBM-20communications bus module, SIL-20A HT auto sampler, CTO-10AS VP oven, and SPD-M20A photodiode array detector, was used to monitor and quantify the reactants and the photoproducts. Separation was performed on a Sinergy Polar-RP column $(150 \times 4.6 \mathrm{~mm}, 5 \mu \mathrm{m}$; Phenomenex Inc., Torrance, CA, USA) using an aqueous solution containing $\mathrm{HCOOH}(25 \mathrm{mM}, \mathrm{pH} 3.5 \pm 0.1)$ as the mobile phase. HPLC runs were monitored by UV/vis spectroscopy at different wavelengths.

Kinetic analysis. To determine the initial rates of His consumption $\left((-\mathrm{d}[\mathrm{His}] / \mathrm{dt})_{0}\right)$ or $\mathrm{P}$ production $\left((\mathrm{d}[\mathrm{P}] / \mathrm{dt})_{0}\right)$, linear plots of the concentration vs. irradiation time were used. Generally, this condition is satisfied only if the concentration of the reactant does not decrease significantly $(<15 \%)$; therefore, for each experiment we considered a period of time that satisfied this condition.

Transient absorption experiments. Laser flash photolysis (LFP) experiments were performed using a LP980 equipment. Briefly, Ptr excitation was performed with the third harmonic at $355 \mathrm{~nm}$ of a Nd:YAG Surelite II-10 laser (6 ns fwhm, $10 \mathrm{~mJ}$ per pulse) (Continuum, Milpitas, CA, USA). The transient absorption spectra and decays of aqueous solutions of Ptr $(\sim 90 \mu \mathrm{M})$, His $(0-1000 \mu \mathrm{M})$, and RSV $(0-51 \mu \mathrm{M})$ previously saturated by bubbling Ar were recorded with the LP980 laser flash photolysis apparatus (Edinburgh Instruments, Livingston, England) linked to a 300 Mhz Tektronik TDS 3012C digital oscilloscope for signal acquisition. Signal analysis was performed using the OriginPro 8.5 software from OriginLab Corporation.

Fraction of the triplet excited state quenched by His, RSV, or $\mathrm{O}_{2}\left(f_{x}\right)$. Taking into account all the reactions involving ${ }^{3} \mathrm{Ptr}^{*}$, the fraction of the triplet excited state quenched by a given species $(X)$ can be calculated as the rate of the reaction of ${ }^{3} \mathrm{Ptr}^{*}$ with $X$ divided into the overall rates of ${ }^{3} \mathrm{Ptr}^{*}$ consumption:

$$
f_{x}=\frac{k_{q}^{X}[X]}{\frac{1}{\tau_{3 \mathrm{Ptr} *}}+k_{q}^{O 2}\left[O_{2}\right]+k_{q}^{X}[X]+k_{q}^{Y}[Y]}
$$

In solutions containing Ptr, His, RSV, and/or $\mathrm{O}_{2}$, and considering the lifetime of the longlived ${ }^{3} \operatorname{Ptr}^{*}\left(\tau^{3 P \operatorname{tr} *}=6.2( \pm 0.7) \mu s\right)$ and the corresponding bimolecular quenching rate constants $\left(k_{\mathrm{q}}\right)$ between ${ }^{3} \mathrm{Ptr}^{*}$ and $\mathrm{O}_{2}$, His, or RSV $\left(1.6 \times 10^{9} \mathrm{M}^{-1} \mathrm{~s}^{-1}\right.$ [22], $1.5 \times 10^{9} \mathrm{M}^{-1} \mathrm{~s}^{-1}$ [23], and $4.9 \times 10^{9} \mathrm{M}^{-1} \mathrm{~s}^{-1}[5]$, respectively), the fractions of ${ }^{3} \mathrm{Ptr}^{*}$ deactivated by $\mathrm{O}_{2}\left(f_{\mathrm{O} 2}\right)$, His $\left(f_{\text {His }}\right)$, or RSV $\left(f_{\text {RSV }}\right)$ can be calculated.

\section{Results}

\subsection{Photosensitized Degradation of Histidine}

Solutions containing $\operatorname{Ptr}(\sim 60 \mu \mathrm{M})$ and His $(\sim 100 \mu \mathrm{M})$ were exposed to UV-A radiation $(365 \mathrm{~nm})$ for different periods of time in the absence of RSV. The experiments were performed in air-equilibrated aqueous solutions at $\mathrm{pH} 4.5$ and concentrations of His and Ptr were determined by HPLC at each irradiation time (experimental section). Kinetic analysis of the remaining substrates was performed. As expected from previous results [15], a 
decrease of the His concentration was observed during the irradiation time, whereas the Ptr concentration did not change (Figure 3 ) in the analyzed time window. HPLC chromatograms also showed a main product $(\mathrm{P})$ at a retention time $\left(t_{\mathrm{R}}\right) 3.6 \mathrm{~min}$, the intensity of which increased with irradiation time (Figure 3).

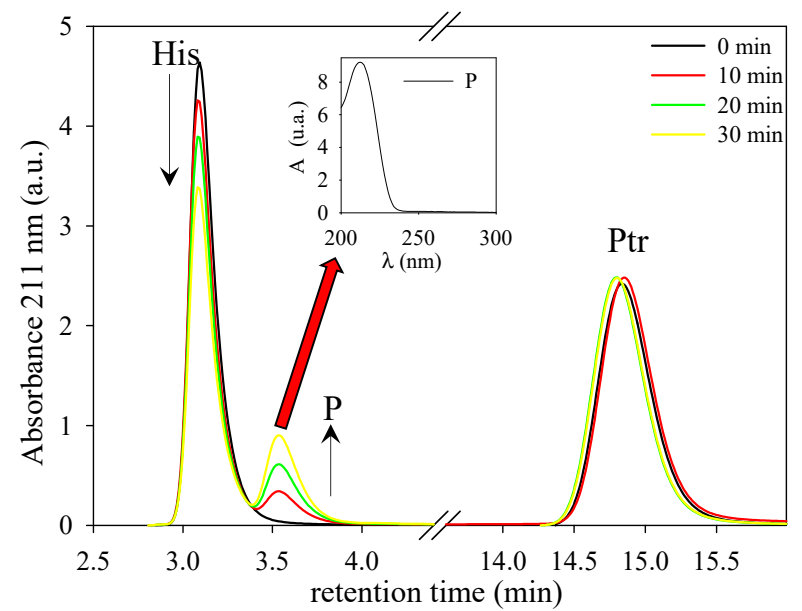

Figure 3. Chromatograms obtained using HPLC, analyzed at $211 \mathrm{~nm}$ from irradiated solutions containing $\operatorname{Ptr}(60 \mu \mathrm{M})$ and His $(100 \mu \mathrm{M})$ at different irradiation times.

Similar experiments were performed in the presence of RSV at different concentrations. The addition of RSV caused evident decreases in the rate of consumption of His (Figure $4 \mathrm{a}$ ) and in the rate of generation of the product $(\mathrm{P})$ (Figure $4 \mathrm{~b}$ ), evidencing the protective capacity of RSV. In all cases, the Ptr concentration remained constant within the irradiation time, whereas the RSV concentration decreased, similarly to what was observed for dGMP [15]. These results suggest that RSV regenerates His, providing photoprotection by acting as a sacrificial antioxidant. The decreases in the initial rates of His consumption and P production were directly proportional to RSV concentration.

As was previously mentioned, Ptr-photosensitized oxidation of His at $\mathrm{pH}<6.0$ starts with a proton-coupled electron transfer (PCET) from the His-protonated form $\left(\mathrm{HisH}^{+}\right.$, $\left.\mathrm{p} K_{\mathrm{a}}=6.0\right)$ to Ptr triplet excited state $\left({ }^{3} \mathrm{Ptr}^{*}\right)$ to form the corresponding radical pair (reaction 2), a neutral $\mathrm{Ptr}$ radical $\left(\mathrm{PtrH}^{\bullet}\right)$ and a His radical cation $\left(\mathrm{His}^{\bullet+}\right)$. In the current experimental conditions, $\mathrm{PtrH}^{\bullet}$ reacts with $\mathrm{O}_{2}$ (reaction 3) to recover Ptr and generate the superoxide anion $\left(\mathrm{O}_{2}{ }^{\bullet-}\right)$. His ${ }^{\bullet+}$ undergoes further reactions to yield oxidation products (reaction 4).

$$
\begin{gathered}
{ }^{3} \mathrm{Ptr} *+\mathrm{HisH}^{+} \stackrel{\mathrm{PCET}}{\longrightarrow} \mathrm{PtrH}^{\bullet}+\mathrm{His}^{\bullet+} \\
\mathrm{PtrH}^{\bullet}+\mathrm{O}_{2} \rightarrow \mathrm{Ptr}+\mathrm{O}_{2}^{\bullet-}+\mathrm{H}^{+} \\
\mathrm{His}^{\bullet}+\stackrel{\mathrm{O}_{2} / \mathrm{O}_{2}^{\bullet-} / \mathrm{H}_{2} \mathrm{O}_{2}}{\longrightarrow} \text { Products }
\end{gathered}
$$

His, RSV, and $\mathrm{O}_{2}$ deactivate ${ }^{3} \mathrm{Ptr}^{*}$, with rate constants in the diffusion control limits (Section 2) $[5,22,23]$. Under the current experimental conditions, the fractions of ${ }^{3} \mathrm{Ptr}^{*}$ deactivated by each quencher are listed in Table 1 . The decreases in the initial consumption relative rate $\left(v / v_{0}\right)$ of His were 0.19 and 0.46 due to the presence of 15 and $45 \mu \mathrm{M}$ of RSV, respectively, being much greater than the expected decrease due to the deactivation of ${ }^{3} \mathrm{Ptr}^{*}$ by RSV, indicating that a faster deactivation of the excited state by the presence of a new quencher is not the only mechanism that protects the amino acid from oxidation. Likewise, the decreases in the initial formation relative rate of $\mathrm{P}$ were of the same magnitude ( 0.13 and 0.46 for 15 and $45 \mu \mathrm{M}$ of RSV, respectively). 


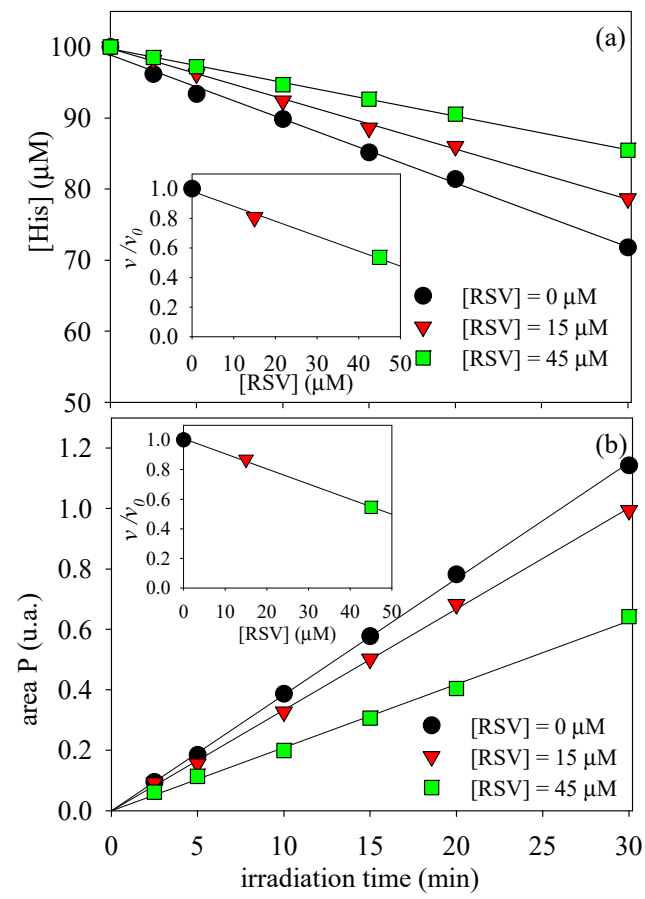

Figure 4. Time evolution of (a) His concentration and (b) area of the peak corresponding to $\mathrm{P}$ registered at $211 \mathrm{~nm}$ during Ptr-photosensitized oxidation in air-equilibrated aqueous solutions ( $\mathrm{pH} 4.5)$ in the absence and presence of RSV $((\mathrm{RSV})=0,15 \mu \mathrm{M}$, and $45 \mu \mathrm{M})$ as a function of irradiation time. Note: $\lambda_{\mathrm{EXC}}=365 \mathrm{~nm}$; Ptr $=60 \mu \mathrm{M}$; His $=100 \mu \mathrm{M}$. Insets: Relative rates $\left(v / v_{0}\right)$ of (a) His consumption and (b) P production at different RSV concentrations.

Table 1. Calculated fractions of ${ }^{3} \mathrm{Ptr}^{*}$ deactivated by His, RSV, and $\mathrm{O}_{2}\left(f_{\mathrm{His}}, f_{\mathrm{RSV}}, f_{\mathrm{O} 2}\right.$, respectively $)$ at different His and RSV concentrations. Ptr $=60 \mu \mathrm{M}$.

\begin{tabular}{ccccc}
\hline$[$ RSV] $\mu \mathbf{M}$ & [His] $\mu \mathbf{M}$ & $f_{\text {His }}$ & $f_{\text {RSV }}$ & $f_{\text {O2 }}$ \\
\hline- & 100 & 0.21 & 0 & 0.56 \\
$15 \mu \mathrm{M}$ & 100 & 0.19 & 0.09 & 0.51 \\
$45 \mu \mathrm{M}$ & 100 & 0.16 & 0.24 & 0.43 \\
- & 700 & 0.65 & 0 & 0.25 \\
$5 \mu \mathrm{M}$ & 700 & 0.64 & 0.01 & 0.24 \\
$15 \mu \mathrm{M}$ & 700 & 0.62 & 0.04 & 0.24 \\
$30 \mu \mathrm{M}$ & 700 & 0.60 & 0.08 & 0.23 \\
\hline
\end{tabular}

Similar experiments were performed both at higher His $\left(7 \times 10^{-4} \mathrm{M}\right)$ and lower RSV $\left(0-30 \times 10^{-6} \mathrm{M}\right)$ concentrations, at which ${ }^{3} \mathrm{Ptr}^{*}$ is mainly deactivated by the amino acid $\left(f_{\text {HIS }}>0.6\right.$, Table 1$)$. Under these experimental conditions, the photoprotective action of RSV was observed (Figure 5), being the deactivation of ${ }^{3} \mathrm{Ptr}^{*}$ by RSV less than $10 \%\left(f_{\mathrm{RSV}}<0.1\right.$, Table 1). Decreases in initials rate of His consumption were higher than expected due to the deactivation of ${ }^{3} \mathrm{Ptr}^{*}$ by RSV in conditions such as PCET from $\mathrm{HisH}^{+}$to ${ }^{3} \mathrm{Ptr}^{*}$ (Reaction 2 ), forming the corresponding radical pair, which is the predominant reaction in which the excited state participates; therefore, the concentrations of $\mathrm{HisH}^{+}$is more or less similar for all analyzed RSV concentrations. Furthermore, initial rates of His consumption were inversely proportional to RSV concentrations (Figure 5, inset), being negative the individual order of reaction for RSV in the overall mechanism, indicating more than an elementary reaction. The inverse proportionality between the His consumption rate and the RSV concentration indicates that RSV participates in a reverse reaction to recover the amino acid. 


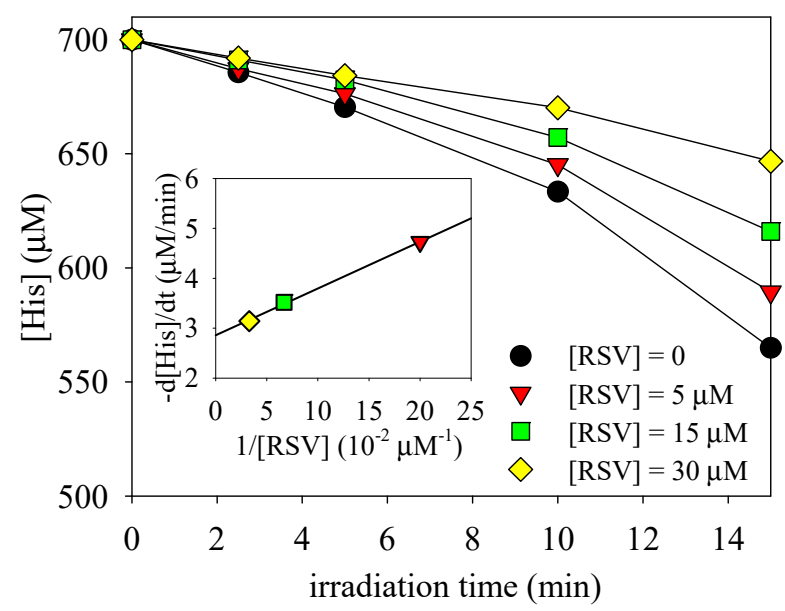

Figure 5. Time evolution of His concentrations during Ptr-photosensitized oxidation in airequilibrated aqueous solutions ( $\mathrm{pH} 4.5)$ in the absence and presence of RSV ((RSV) $=0,5 \mu \mathrm{M}$, $15 \mu \mathrm{M}$, and $30 \mu \mathrm{M})$ as a function of irradiation time. Note: $\lambda_{\mathrm{EXC}}=365 \mathrm{~nm} ; \operatorname{Ptr}=60 \mu \mathrm{M} ; \mathrm{His}=700 \mu \mathrm{M}$. Inset: Rates of His consumption at different RSV concentrations.

These results clearly reveal that photoprotection by RSV occurs at a step after the reaction between ${ }^{3} \mathrm{Ptr}^{*}$ and $\mathrm{HisH}^{+}$(Reaction 2). Considering the kinetics analysis performed here and previous results for dGMP and Tyr oxidation [5,8], where prevention of oneelectron oxidation of the biomolecule by RSV was demonstrated, we can assume that His is recovered from $\mathrm{His}^{\bullet+}$ after receiving an electron from RSV.

\subsection{Laser Flash Photolysis Experiments}

The differential transient absorption spectra of solutions containing $\operatorname{Ptr}(93 \mu \mathrm{M})$ recorded after the $355 \mathrm{~nm}$ laser pulse showed the typical band between 400 and $550 \mathrm{~nm}$ (Figure 6), with a biexponential decay with lifetimes of $6.2( \pm 0.7) \times 10^{-6} \mathrm{~s}$ and $0.5( \pm 0.2) \times 10^{-6} \mathrm{~s}$ corresponding to lactam and lactim tautomeric species of ${ }^{3} \mathrm{Ptr}^{*}$, respectively, similar to those previously reported [22]. Both tautomeric forms are deactivated by $\mathrm{HisH}^{+}$with bimolecular quenching rate constants in the range of the diffusion-controlled limit, being $1.5( \pm 0.2) \times 10^{9} \mathrm{M}^{-1} \mathrm{~s}^{-1}$ for the long-lived and $3( \pm 1) \times 10^{9} \mathrm{M}^{-1} \mathrm{~s}^{-1}$ for the short-lived triplet excited states [23]. Additionally, it has been observed that only the Ptr long-lived species (lactam tautomer) participates in photosensitized electron transfer reactions [22,23].

The differential transient absorption spectra of aqueous solutions containing Ptr $(93 \mu \mathrm{M})$ and His $\left(1 \times 10^{-3} \mathrm{M}\right)$ were recorded between 300 and $600 \mathrm{~nm}$ in the absence and the presence of RSV (Figure 7). In the absence of RSV, a weak wide absorption band between 400 and $500 \mathrm{~nm}$ was observed (Figure 7, black dots), characteristic of the Ptr radical anion $\left(\mathrm{Ptr}^{\bullet-}\right)$ [24], which is strong evidence of the participation of ${ }^{3} \mathrm{Ptr}^{*}$ in an electron transfer reaction with HisH ${ }^{+}$(Reaction 2). The ${ }^{3} \mathrm{Ptr}^{*}$ lifetime value obtained by fitting the LFP signal at $430 \mathrm{~nm}\left(\tau_{\mathrm{EXP}}^{3 \mathrm{Ptr} *}\right)$ was $0.40( \pm 0.04) \times 10^{-6} \mathrm{~s}$, similar to the expected lifetime $\left(\tau_{\mathrm{CAL}}^{3 \mathrm{Ptr} *}, 0.60 \times 10^{-6} \mathrm{~s}\right)$. In this experimental condition, the calculated fraction of ${ }^{3} \mathrm{Ptr}^{*}$ quenched by His $\left(f_{\text {His }}^{3 \mathrm{Ptr} *}\right)$ is 0.90 .

In the presence of RSV, a new long-lived absorption band with maxima at $400 \mathrm{~nm}$ was observed (Figure 7, red triangles), similar to that reported for the RSV neutral radical (RSV $(-\mathrm{H})^{\bullet}$ ) [25], indicating an electron transfer step to an electron acceptor. Traces recorded at $410 \mathrm{~nm}$ for different RSV concentrations followed first-order kinetics and showed an increase in the absorbance at infinite time proportional to the RSV concentration, indicating a higher $\mathrm{RSV}(-\mathrm{H})^{\bullet}$ concentration (Figure 8). The corresponding $\mathrm{RSV}(-\mathrm{H})^{\bullet}$ formation lifetimes $\left(\tau_{\mathrm{EXP}}^{\mathrm{RSV}(\mathrm{H})} \bullet\right)$ in solutions containing His $\left(1 \times 10^{-3} \mathrm{M}\right)$ were calculated by fitting the signal registered at 410 for each RSV concentration $\left(0-51 \times 10^{-6} \mathrm{M}\right.$, Table 2$)$, being the formation lifetime one order of magnitude higher than the expected ${ }^{3} \mathrm{Ptr}^{*}$ lifetime $\left(\tau_{\mathrm{CAL}}^{3 \mathrm{Ptr} *}\right)$. As expected for a bimolecular reaction, $\tau_{\mathrm{EXP}}^{\mathrm{RSV}(\mathrm{H})} \bullet$ decreased with RSV concentration, 
but all values obtained were much higher than the ${ }^{3} \mathrm{Ptr}^{*}$ lifetime experimentally obtained $\left(\tau_{\mathrm{EXP}}^{\mathrm{3Ptr} *}, 0.40( \pm 0.04) \times 10^{-6} \mathrm{~s}\right.$, Figure 8 , red trace) in the absence of the antioxidant. In the observed range of formation lifetimes for $\operatorname{RSV}(-\mathrm{H})^{\bullet}(1.7 \mu \mathrm{s}-3.0 \mu \mathrm{s}),{ }^{3} \mathrm{Ptr}^{*}$ was no longer present in the solution so could not be responsible for its formation. These results clearly exclude an electron transfer reaction between long-lived ${ }^{3} \mathrm{Ptr}^{*}$ and RSV.

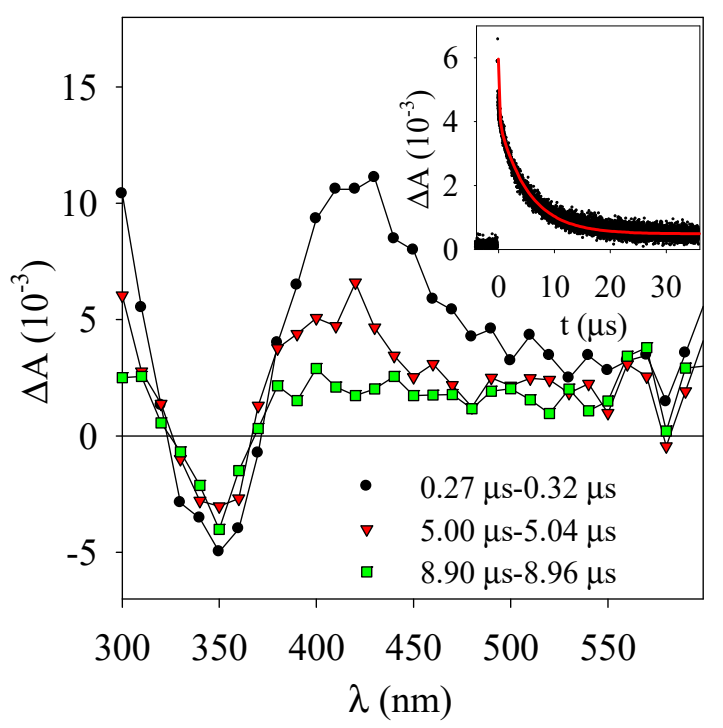

Figure 6. Differential transient absorption spectra registered at different range times after the laser pulse of deaerated aqueous solution containing $P \operatorname{tr}(93 \mu \mathrm{M})$ Inset: Time dependence of the absorbance at $430 \mathrm{~nm}\left(\lambda_{\mathrm{EXC}}=355 \mathrm{~nm} ; \mathrm{pH}=4.0\right)$.

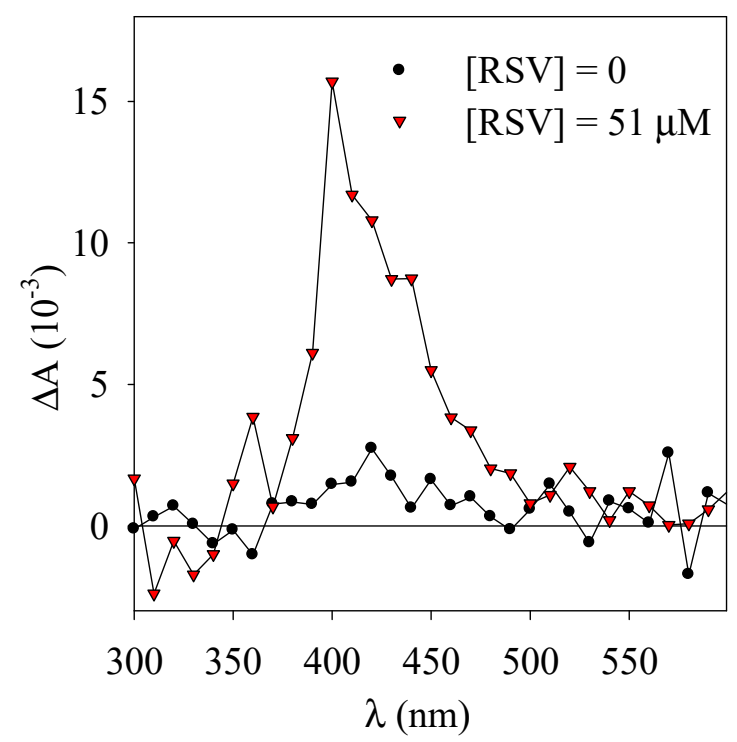

Figure 7. Differential transient absorption spectra of deaerated aqueous solutions containing Ptr $(93 \mu \mathrm{M})$ and His $(1000 \mu \mathrm{M})$ in the absence $(\bullet)$ and presence of RSV $(51 \mu \mathrm{M}, \boldsymbol{\nabla})$ registered $5 \mu$ s after the laser pulse. Note: $\lambda_{\mathrm{EXC}}=355 \mathrm{~nm}$; $\mathrm{pH}=4.0$. 


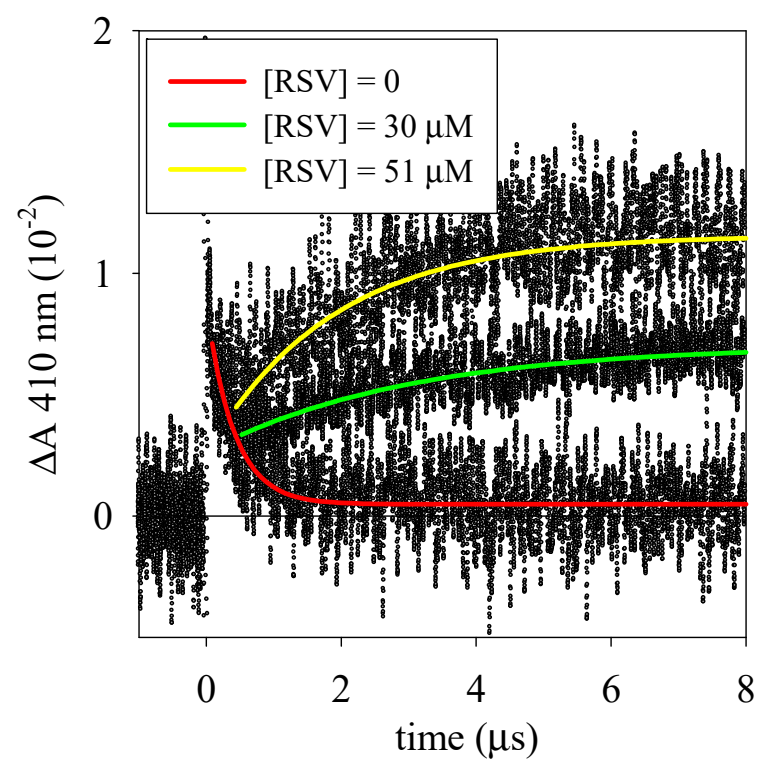

Figure 8. Traces recorded at $410 \mathrm{~nm}$ for different RSV concentrations ((RSV) $=0,30$, and $51 \mu \mathrm{M})$. The experiments were performed in Ar-saturated aqueous solutions $\left(\lambda_{\mathrm{EXC}}=355 \mathrm{~nm}\right.$; Ptr $=93 \mu \mathrm{M}$; His $=1000 \mu \mathrm{M})$.

Table 2. Experimental RSV $(-\mathrm{H})^{\bullet}$ formation lifetime $\left(\tau_{\mathrm{EXP}}^{\mathrm{RSV}(\mathrm{H})} \bullet\right)$ and calculated or experimental ${ }^{3} \mathrm{Ptr}^{*}$ lifetime (and $\tau_{\mathrm{CAL}}^{3 \mathrm{P} t r *}$ or $\tau_{\mathrm{EXP}}^{3 \mathrm{Ptr} *}$, respectively) values from deaerated aqueous solutions of Ptr $(93 \mu \mathrm{M})$ and His $(1000 \mu \mathrm{M})$ at different RSV concentrations.

\begin{tabular}{cccc}
\hline$\left[\mathbf{H i s H}^{+}\right]=\mathbf{1 0 0 0} \boldsymbol{\mu M}$ & $\boldsymbol{\tau}_{\mathbf{E X P}}^{\mathbf{R S V}(\mathbf{H})}(\boldsymbol{\mu s})$ & $\boldsymbol{\tau}_{\mathbf{C A L}}^{3 \mathbf{P t r}^{*}}(\boldsymbol{\mu s})$ & $\boldsymbol{\tau}_{\mathbf{E X P}}^{3 \text { Ptr* }^{*}}(\boldsymbol{\mu s})$ \\
\hline$[\mathrm{RSV}]=0$ & - & 0.60 & 0.40 \\
{$[\mathrm{RSV}]=30 \mu \mathrm{M}$} & 3.0 & 0.55 & - \\
{$[\mathrm{RSV}]=35 \mu \mathrm{M}$} & 2.5 & 0.55 & - \\
{$[\mathrm{RSV}]=40 \mu \mathrm{M}$} & 2.4 & 0.54 & - \\
{$[\mathrm{RSV}]=45 \mu \mathrm{M}$} & 2.2 & 0.53 & - \\
{$[\mathrm{RSV}]=51 \mu \mathrm{M}$} & 1.7 & 0.52 & - \\
\hline
\end{tabular}

\section{Discussion}

As was previously reported, the initial step into Ptr-photosensitized degradation of His at $\mathrm{pH}$ levels below 6 is a proton-coupled electron transfer (PCET) from $\mathrm{HisH}^{+}$to ${ }^{3} \mathrm{Ptr}^{*}$, yielding the corresponding pair of radicals, a pterin neutral radical $\left(\mathrm{PtrH}^{\bullet}\right)$ and a histidine radical cation $\left(\mathrm{His}^{\bullet+}\right)$ (reaction 2) [15]. This later radical undergoes further oxidation and a main product can be observed (Figure 2). Under aerobic conditions, Ptr is not consumed during His oxidation, since it is recovered in an electron transfer reaction from the Ptr radical anion to $\mathrm{O}_{2}$, forming a superoxide anion (reaction 3) [15]. The elimination of $\mathrm{PtrH}^{\bullet}$ by $\mathrm{O}_{2}$ avoids the recombination with $\mathrm{His}^{\bullet+}$ and, in consequence, His is irreversibly consumed (Scheme 1).

The addition of RSV to the solution clearly slowed down the rate of His consumption (Figures 4 and 5), revealing the protective action of this compound. RSV deactivated ${ }^{3} \mathrm{Ptr}^{*}$, although the decrease in His consumption was greater than expected given the deactivation of the excited state. Moreover, similar protection was observed in solutions containing His at higher concentrations $\left(7 \times 10^{-4} \mathrm{M}\right)$, whereby the triplet excited state was mainly deactivated by His, proving that RSV photoprotection is not due to the deactivation of the excited state of the sensitizer. 


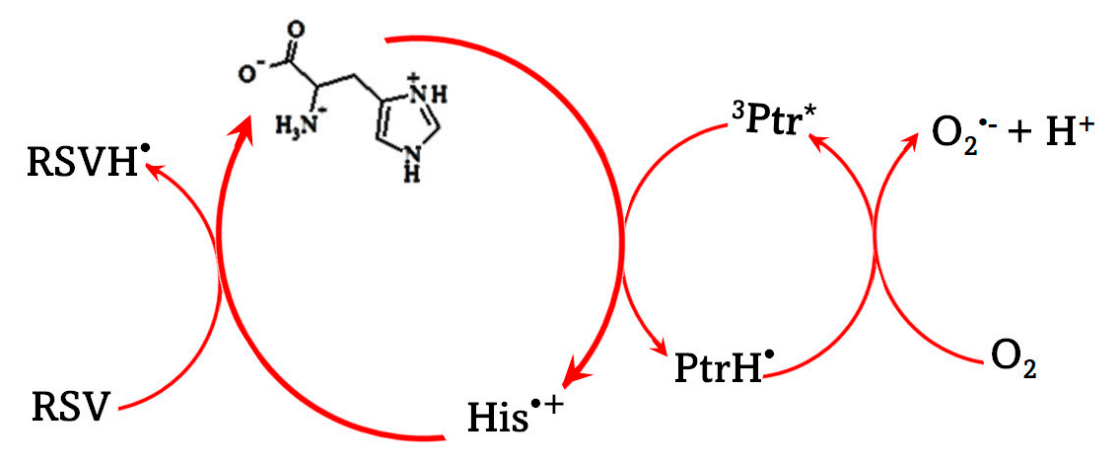

Scheme 1. Mechanism of RSV antioxidant action on Ptr-photosensitized His degradation.

Under experimental conditions such as almost all ${ }^{3} \mathrm{Ptr}^{*}$ was deactivated by His, a characteristic transient absorption spectra corresponding to $\operatorname{RSV}(-\mathrm{H})^{\bullet}$ was observed (Figure 7), revealing that RSV participates in an electron transfer reaction. The formation lifetime

of $\operatorname{RSV}(-\mathrm{H})^{\bullet}\left(\tau_{\mathrm{EXP}}^{\mathrm{RSV}(\mathrm{H}) \bullet}\right)$ was found to be higher than that of ${ }^{3} \mathrm{Ptr}^{*}$ (Figure 8, Table 2), indicating that the radical observed was not formed in a reaction with this excited species. Furthermore, since His is consumed at a slower rate in the presence of RSV, and considering that decreases in the His consumption rate are inversely proportional to RSV concentration, we can consider that $\mathrm{RSV}(-\mathrm{H})^{\bullet}$ is a product of the reaction between $\mathrm{His}^{\bullet+}$ and RSV (Reaction 5), whereby His is recovered.

$$
\mathrm{His}^{\bullet+}+\mathrm{RSV} \rightarrow \mathrm{HisH}^{+}+\mathrm{RSV}(-\mathrm{H})^{\bullet}
$$

\section{Conclusions}

In this work, kinetic studies were carried out on the antioxidant capacity of resveratrol (RSV) during the photosensitized oxidation of the amino acid histidine (His). Under UV-A exposure (365 nm) and in the presence of pterin (Ptr), the mechanism involved in the oxidation of His is a proton-coupled electron transfer (PCET) from $\mathrm{HisH}^{+}$to the Ptr triplet excited state $\left({ }^{3} \mathrm{Ptr}^{*}\right)$, yielding the corresponding pair of radical $\left(\mathrm{His}^{\bullet+}\right.$ and $\mathrm{PtrH}^{\bullet}$, respectively). When adding RSV to the solution, evident decreases in the consumption initial rates of His were observed, and RSV radical $\left(\mathrm{RSV}(-\mathrm{H})^{\bullet}\right)$ was also detected. The formation lifetime for $\operatorname{RSV}(-\mathrm{H})^{\bullet}$ exceeded the lifetime for ${ }^{3} \mathrm{Ptr}^{*}$, indicating that it is not a product of a reaction between RSV and ${ }^{3} \mathrm{Ptr}^{*}$. Taking all of these experimental results together, it is clear that the lower consumption rate of His is the result of a reaction between $\mathrm{His}^{\bullet+}$ and RSV that recovers the amino acid, and we can certainly conclude that RSV provides protection against its oxidation.

All experimental evidence presented in this work indicates that RSV reduces the rate of His consumption by acting as an electron donor, allowing the recovery of the amino acid after it has been oxidized in a PCET reaction with Ptr in its triplet excited state. Elucidating how RSV protects His from photosensitized oxidation, in addition to revealing its potential antioxidant role in high oxidative stress environments, it provides a molecular basis for understanding its mechanism of action. These results are of great relevance, since His is a critical amino acid for the functionality of several enzymes and it is also extremely susceptible to oxidation in electron transfer reactions. Since the most energetic component of solar radiation is UV-A, the photoprotection that RSV provides to prevent the oxidation of biomolecules under UV exposure should be considered in food technology, medicinal, and cosmetic products.

Author Contributions: Methodology, J.R.N.R.; formal analysis, J.R.N.R., M.L.D., and C.L.; investigation, J.R.N.R., M.L.D., and C.L.; resources, M.L.D. and C.L.; writing-original draft preparation, C.L.; writing-review and editing, J.R.N.R., M.L.D., and C.L.; project administration, M.L.D. and C.L.; funding acquisition, M.L.D. and C.L. All authors have read and agreed to the published version of the manuscript. 
Funding: The present work was partially supported by Agencia Nacional de Promoción Científica y Tecnológica (ANPCyT-Grant PICT-2017-0925) Consejo Nacional de Investigaciones Científicas y Técnicas (CONICET-Grant P-UE 2017 22920170100100C) and the Universidad Nacional de La Plata (UNLP-Grant X840).

Acknowledgments: J.R.N.R. thanks CONICET for graduate research fellowships. M.L.D. and C.L. are research members of CONICET.

Conflicts of Interest: The authors declare no conflict of interest.

\section{References}

1. Langcake, P.; Pryce, R.J. The production of resveratrol by Wis vinifera and other members of the Vitaceae as a response to infection or injury. Physiol. Plant Pathol. 1976, 9, 77-86. [CrossRef]

2. Harborne, J.B. Higher Plant-Lower Plant Interactions: Phytoalexins and Phytotoxins in Introduction to Ecological Biochemistry, 4th ed.; Academic Press: Cambridge, MA, USA, 1993; pp. 264-297.

3. Colica, C.; Milanović, M.; Milić, N.; Aiello, V.; De Lorenzo, A.; Abenavoli, L. A systematic review on natural antioxidant properties of resveratrol. Nat. Prod. Commun. 2018, 13, 1195-1203. [CrossRef]

4. Davies, J.M.S.; Cillard, J.; Friguet, B.; Cadenas, E.; Cadet, J.; Cayce, R.; Fishmann, A.; Liao, D.; Bulteau, A.L.; Derbré, F. The Oxygen Paradox, the French Paradox, and age-related diseases. GeroScience 2017, 39, 499-550. [CrossRef]

5. Neyra Recky, J.R.; Gaspar Tosato, M.; Serrano, M.P.; Thomas, A.H.; Dántola, M.L.; Lorente, C. Evidence of the effectiveness of Resveratrol in the prevention of guanine one-electron oxidation: Possible benefits in cancer prevention. Phys. Chem. Chem. Phys. 2019, 21, 16190-16197. [CrossRef] [PubMed]

6. Baptista, M.S.; Cadet, J.; Di Mascio, P.; Ghogare, A.A.; Greer, A.; Hamblin, M.R.; Lorente, C.; Nunez, S.C.; Simoes Ribeiro, M.; Thomas, A.H.; et al. Type I and Type II Photosensitized Oxidation Reactions: Guidelines and Mechanistic Pathways. Photochem. Photobiol. 2017, 93, 912-919. [CrossRef]

7. Pattison, D.I.; Rahmanto, A.S.; Davies, M.J. Photo-oxidation of proteins. Photochem. Photobiol. Sci. 2012, 11, 38-53. [CrossRef] [PubMed]

8. Neyra Recky, J.R.; Serrano, M.P.; Dántola, M.L.; Lorente, C. Oxidation of tyrosine: Antioxidant mechanism of L-DOPA disclosed. Free Radic. Biol. Med. 2021, 16, 360-367. [CrossRef] [PubMed]

9. Muralla, R.; Sweeney, C.; Stepansky, A.; Leustek, T.; Meinke, D. Genetic dissection of histidine biosynthesis in Arabidopsis. Plant. Physiol. 2007, 144, 890-903. [CrossRef]

10. Tiwari, M.K.; Hägglund, P.M.; Max Møller, I.; Davies, M.J.; Bjerrum, M.J. Copper ion $/ \mathrm{H}_{2} \mathrm{O}_{2}$ oxidation of Cu/Zn-Superoxide dismutase: Implications for enzymatic activity and antioxidant action. Redox Biol. 2019, 26, 101262. [CrossRef]

11. Guerra, W.D.; Odella, E.; Urrutia, M.N.; Liddell, P.A.; Moore, T.A.; Moore, A.L. Models to study photoinduced multiple proton coupled electron transfer processes. J. Porphyr. Phthalocyanines 2021, 25, 674-682. [CrossRef]

12. Uchida, K. Histidine and lysine as targets of oxidative modification. Amino Acids 2003, 25, 249-257. [CrossRef]

13. Tsentalovich Yu, P.; Lopez, J.J.; Hore, P.J.; Sagdeev, R.Z. Mechanisms of reactions of flavin mononucleotide triplet with aromatic amino acids. Spectrochim. Acta Part A 2002, 58, 2043-2050. [CrossRef]

14. Agon, V.V.; Bubb, W.A.; Wright, A.; Hawkins, C.L.; Davies, M.J. Sensitizer-mediated photooxidation of histidine residues: Evidence for the formation of reactive side-chain peroxides. Free Radic. Biol. Med. 2006, 40, 698-710. [CrossRef] [PubMed]

15. Castaño, C.; Oliveros, E.; Thomas, A.H.; Lorente, C. Histidine oxidation photosensitized by pterin: pH dependent mechanism. J. Photochem. Photobiol. B Biol. 2015, 153, 483-489. [CrossRef] [PubMed]

16. Matheson, I.B.C.; Lee, J. Chemical reaction rates of amino acids with singlet oxygen. Photochem. Photobiol. 1979, 29, 879-881. [CrossRef]

17. Lorente, C.; Serrano, M.P.; Vignoni, M.; Dántola, M.L.; Thomas, A.H. A model to understand type I oxidations of biomolecules photosensitized by pterins. J. Photochem. Photobiol. 2021, 7, 100045. [CrossRef]

18. Lorente, C.; Petroselli, G.; Dántola, M.L.; Oliveros, E.; Thomas, A.H. Electron transfer initiated reactions photoinduced by pterins. Pteridines 2011, 22, 111-119. [CrossRef]

19. Oliveros, E.; Dántola, M.L.; Vignoni, M.; Thomas, A.H.; Lorente, C. Production and quenching of reactive oxygen species by pterin derivatives, an intriguing class of biomolecules. Pure Appl. Chem. 2011, 83, 801-811. [CrossRef]

20. Braun, A.M.; Maurette, M.T.; Oliveros, E. Photochemical Technology; Wiley: Chichester, UK; New York, NY, USA, 1991 ; Chapter 2.

21. Kuhn, H.J.; Braslavsky, S.E.; Schmidt, R. Chemical actinometry (IUPAC technical report). Pure Appl. Chem. 2004, 76, 2105-2146. [CrossRef]

22. Serrano, M.P.; Lorente, C.; Borsarelli, C.D.; Thomas, A.H. Unravelling the degradation mechanism of purine nucleotides photosensitized by pterins: The role of charge-transfer steps. ChemPhysChem 2015, 16, 2244-2252. [CrossRef]

23. Castaño, C.; Serrano, M.P.; Lorente, C.; Borsarelli, C.D.; Thomas, A.H. Quenching of the singlet and triplet excited states of pterin by amino acids. Photochem. Photobiol. 2019, 95, 220-226. [CrossRef] [PubMed]

24. Reid, L.O.; Castaño, C.; Dántola, M.L.; Lhiaubet-Vallet, V.; Miranda, M.A.; Marin, M.L.; Thomas, A.H. A novel synthetic approach to tyrosine dimers based on pterin photosensitization. Dyes Pigm. 2017, 147, 67-74. [CrossRef]

25. Džeba, I.; Pedzinski, T.; Mihaljevi, B. Photophysical and photochemical properties of resveratrol. J. Photochem. Photobiol. A Chem. 2015, 299, 118-124. [CrossRef] 